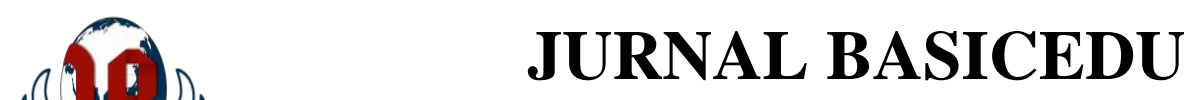

Volume 5 Nomor 4 Tahun 2021 Halaman 2164 - 2170

Research \& Learning in Elementary Education

https://jbasic.org/index.php/basicedu

\title{
Faktor-Faktor Penyebab Peningkatan Nilai Siswa Sekolah Dasar dalam Pembelajaran Jarak Jauh pada Masa Pandemi Covid-19
}

\author{
Nurul Aini Putri ${ }^{1 凶}$, Zulela M.S ${ }^{2}$, Otib Satibi $\mathbf{H}^{3}$ \\ Universitas Negeri Jakarta, Indonesia ${ }^{1,2,3}$

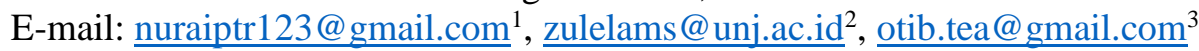

\begin{abstract}
Abstrak
Tujuan dari penelitian ini adalah untuk mendapatkan dan mendeskripsikan informasi mengenai faktor yang menyebabkan meningkatnya nilai siswa sekolah dasar pada pembelajaran jarak jauh pandemi covid-19. Metode penelitian yang dipakai dalam penelitian ini adalah metode penelitian kualitatif deskriptif dengan menggunakan teknik pengumpulan data yaitu teknik wawancara dan angket. Dalam penelitian ini responden sebanyak 22 orang, terdiri dari dua orang guru yaitu guru SDN Rawamangun 01 dan guru SDT Pelita Hati, sepuluh orang siswa kelas 2 SDN Rawamangun 01 dan sepuluh orang siswa kelas 6 SDT Pelita Hati. Hasil penelitian yaitu terdapat empat faktor yang menyebabkan meningkatnya nilai siswa pada masa pembelajaran jarak jauh pandemi covid-19 yaitu, kemandirian belajar siswa, peran orang tua, kemudahan teknologi, dan bimbingan belajar. Adapun faktor yang membedakan siswa kelas rendah dengan kelas tinggi yaitu, faktor yang menyebabkan peningkatan nilai pada siswa kelas rendah yaitu peran orang tua, kemudahan teknologi, dan bimbingan belajar. Sedangkan faktor yang menyebabkan peningkatan nilai siswa kelas tinggi yaitu kemandirian belajar siswa.
\end{abstract}

Kata Kunci: faktor, covid-19, pembelajaran jarak jauh.

\section{Abstract}

The purpose of this study was to obtain and describe information about the factors that led to the increase in grades of elementary school students in distance learning during the COVID-19 pandemic. The research method used in this research is descriptive qualitative research method using data collection techniques, namely interview and questionnaire techniques. In this study, there were 22 respondents, consisting of two teachers, namely SDN Rawamangun 01 teachers and SDT Pelita Hati teachers, ten grade 2 students at SDN Rawamangun 01, and ten grade 6 students at SDT Pelita Hati. The results of the study showed that there were four factors that led to an increase in student scores during the distance learning period of the covid-19 pandemic, namely, student learning independence, the role of parents, the convenience of technology, and tutoring. The factors that distinguish low-grade students from high-grade students are factors that cause an increase in grades for low-grade students, namely the role of parents, the ease of technology, and tutoring. While the factors that cause an increase in the value of high-grade students are student learning independence.

Keywords: factor, covid-19, formatting, distance learning.

Copyright (c) 2021 Nurul Aini Putri, Zulela M.S, Otib Satibi H

$\triangle$ Corresponding author :

Email : nuraiptr123@gmail.com

DOI $\quad$ : https://doi.org/10.31004/basicedu.v5i4.1171 
2165 Faktor-Faktor Penyebab Peningkatan Nilai Siswa Sekolah Dasar dalam Pembelajaran Jarak Jauh pada Masa Pandemi Covid-19 - Nurul Aini Putri, Zulela M.S, Otib Satibi H

DOI: https://doi.org/10.31004/basicedu.v5i4.1171

\section{PENDAHULUAN}

Pada bulan Desember tahun 2019, dunia dikejutkan dengan hadirnya virus corona (covid-19) yang pertama kali hadir di kota Wuhan, China. Semakin hari virus ini menyebar dengan begitu cepat dengan rantai penularan yaitu pada manusia. Coronavirus Disease 2019 (Covid-19) adalah penyakit jenis baru yang belum pernah teridentifikasi sebelumnya pada manusia. Virus penyebab covid-19 dinamakan Sars-Cov-2. Sampai saat ini, belum dapat diketahui dengan pasti penyebab dan asal virus ini darimana. Namun, tanda dan gejala umum yang nampak dari infeksi covid-19 menurut Tosepu dalam Ririn yaitu gejala gangguan pernapasan akut seperti demam, batuk, dan sesak nafas. Masa inkubasi atau waktu dari terpaparnya virus covid-19 ini adalah 5 sampai 6 hari mengalami demam, batuk, dan sesak nafas (Putri, 2020). Dengan hadirnya virus covid-19 telah menarik perhatian dunia dan dengan percepatan penyebaran yang sudah hampir meneyeluruh ke seluruh penjuru dunia, organisasi kesehatan dunia (WHO) pada 30 Januari 2020 menyatakan covid-19 sebagai darurat kesehatan masyarakat yang menjadi perhatian internasional (Dong et al., 2020). Wabah virus covid-19 tidak hanya merupakan masalah nasional suatu negara, namun sudah merupakan masalah global.

Virus covid-19 hadir di Indonesia pada awal bulan Maret 2020. Kehadiran virus tersebut membuat banyak masyarakat resah. Virus covid-19 dengan cepat menyebar dan menjadi sebuah tantangan dan permasalahan baru yang harus dihadapi. Pandemi covid-19 yang masih berlangsung sampai saat ini memberikan dampak yang luas dalam kehidupan. Salah satunya pada bidang pendidikan.

Setelah masuknya virus covid-19 di Indonesia, sekolah diliburkan selama dua minggu untuk pencegahan penularan. Namun, karena penyebarannya begitu cepat dan semakin memakan banyak korban, pada akhirnya pemerintah melakukan upaya yaitu memberlakukan program belajar dari rumah atau yang dikenal dengan pembelajaran jarak jauh untuk tetap terlaksananya pembelajaran.

Pembelajaran jarak jauh adalah pembelajaran yang dilakukan oleh siswa dan guru yang tidak hadir secara fisik bersamaan di sekolah (Setiawan, 2020). Pembelajaran yang sebelumnya dilaksanakan secara langsung atau tatap muka beralih menjadi secara online atau daring dengan menggunakan pemanfaatan teknologi.

Praktik pembelajaran jarak jauh di Indonesia dimulai pada akhir Maret 2020 setelah sebelumnya sekolah diliburkan selama dua minggu. Para pendidik mengimplementasikan dengan cara-cara yang beragam dalam pelaksanaan belajar jarak jauh. Pembelajaran jarak jauh yang dilakukan oleh pendidik dan peserta didik adalah menggunakan platform aplikasi, website, sosial media, dan lain sebagainya yang dapat menunjang pelaksanaan pembelajaran. Pembelajaran jarak jauh merupakan sebuah inovasi dalam dunia pendidikan untuk menjawb tantangan akan ketersediaan sumber belajar yang variatif (Dewi, 2020). Semua sarana tersebut merupakan hasil dari perkembangan teknologi komunikasi dan informasi yang dimanfaatkan penggunaannya dalam pembelajaran.

Pembelajaran jarak jauh yang dilakukan di SDN Rawamangun 01 dan SDT Pelita Hati, dilakukan secara maksimal. Pembelajaran dilakukan secara daring berbasis digital dengan menggunakan berbagai platform. Seperti zoom, youtube, video call whatsapp, google form, serta penggunaan buku paket. Guru secara intens mengajarkan kepada siswa, sehingga pembelajaran jarak jauh ini dapat berjalan seperti pembelajaran tatap muka. Guru melakukan berbagai upaya agar siswa dapat menerima pembelajaran. Dalam pengambilan nilai, guru menggunakan google form, tes lisan melalui video call, dan tertulis lalu difoto.

Berdasarkan hasil wawancara dengan guru SDN Rawamangun 01 dan SDT Pelita hati, hasil belajar siswa selama pembelajaran jarak jauh ini, nilai siswa mengalami peningkatan yang cukup tajam dari pembelajaran tatap muka pada sebelumnya. Dalam penerapan pembelajaran jarak jauh, guru mengamati siswa kebanyakan mulai merasa bosan dan kurangnya minat dalam belajar. Minat belajar merupakan salah satu unsur yang sangat penting untuk keberhasilan belajar yang dimiliki peserta didik (Yunitasari \& Hanifah, 2020). Dengan sistem pembelajaran jarak jauh yang tidak berlangsung secara tatap muka, sehingga guru tidak dapat mengetahui apakah hasil kerja siswa merupakan murni dari kemampuan atau pemahaman siswa tersebut atau bukan. Oleh 
karena itu, peneliti tertarik untuk mencari informasi mengenai faktor yang menyebabkan meningkatnya nilai peserta didik pada proses pembelajaran jarak jauh. Rumusan masalah dalam penelitian ini: (1) Apa saja faktor yang menyebabkan meningkatnya nilai siswa selama masa pembelajaran jarak jauh?, (2) Apakah ada faktor yang membedakan dari meningkatnya nilai siswa selama pembelajaran jarak jauh pada siswa kelas rendah dengan siswa kelas tinggi?. Tujuan dari penelitian ini adalah untuk mendapatkan dan mendeskripsikan informasi mengenai faktor yang menyebabkan meningkatnya nilai siswa pada pembelajaran jarak jauh.

\section{METODE}

Penelitian menggunakan metode kualitatif deskriptif. Menurut Williams dalam (Sutisna, 2021), penelitian kualititatif atau naturalistik adalah suatu penilitian yang dilaksanakan dengan berdasarkan pada latar alamiah yang terjadi di lapangan. Menurut Bogdan dan Taylor dalam (Suwendra, 2018), penelitian kualitatif merupakan langkah-langkah penelitian yang menghasilkan data deskriptif berupa kata-kata tertulis atau lisan dari orangorang dan perilaku yang dapat diamati.

Penelitian dilakukan di dua sekolah yaitu SDN Rawamangun 01 dan SDT Pelita Hati. Subjek penelitian ini adalah guru, siswa kelas rendah, dan siswa kelas tinggi yang mengikuti pembelajaran jarak jauh selama pandemi covid-19. Teknik pengumpulan data menggunakan wawancara dan angket. Instrumen penelitian ini berupa angket yang disebar dengan bantuan google formulir pada bulan April 2021. Responden yang mengisi yaitu 10 orang siswa kelas 2 SDN Rawamangun dan 10 orang siswa kelas 6 SDT Pelita Hati. Wawancara semiterstruktur dilakukan dengan guru kelas 2 SDN Rawamangun 01 dan guru kelas 6 SDT Pelita Hati secara daring. Data yang diperoleh kemudian dianalisis menggunakan analisis kualitatif.

\section{HASIL DAN PEMBAHASAN}

Hasil dari penelitian ini didasari oleh dua rumusan masalah yaitu (1) Apa saja faktor yang menyebabkan meningkatnya nilai siswa selama masa pembelajaran jarak jauh, dan (2) Apakah ada faktor yang membedakan dari meningkatnya nilai siswa selama pembelajaran jarak jauh pada siswa kelas rendah dengan siswa kelas tinggi. Berdasarkan hasil angket yang telah diisi oleh 10 orang siswa kelas 2 SDN Rawamangun 01 dan 10 orang siswa kelas 6 SDT Pelita Hati, didapati hasil penelitian yang akan dideskripsikan yaitu (1) Kemandirian Belajar Siswa, (2) Peran Orang tua, (3) Kemudahan Teknologi, (4) Bimbingan Belajar.

\section{Kemandirian Belajar Siswa}

Dalam praktik pembelajaran jarak jauh di masa pandemi ini sangat mengutamakan pada kemandirian siswa dalam belajar dari rumah. Kemandirian ini menuntut tanggung jawab yang besar pada diri siswa. Kemandirian belajar siswa yang berdampak pada meningkatnya nilai siswa membuktikan bahwa kemampuan siswa memiliki karakter mandiri melalui belajar mandiri tanpa bantuan orang lain (Rozi et al., 2021).

Dari hasil angket yang telah disebar, sebanyak 9 dari 10 siswa kelas 2 menjawab "ya" pada pernyataan dalam mengerjakan tugas sekolah dibantu oleh orang tua. Sedangkan sebanyak 10 dari 10 siswa kelas 6 menjawab "tidak" pada pernyataan dalam mengerjakan tugas sekolah dibantu oleh orang tua. Dapat terlihat bahwa siswa kelas tinggi dapat dengan mandiri mengerjakan tugas sekolahnya, adapun siswa kelas rendah masih perlu dibantu oleh orang tua.

Kemandirian siswa dalam belajar berdampak pada meningkatnya nilai akademik. Dalam kemandirian belajar, inisiatif merupakan indikator yang sangat mendasar (Sulastrini \& Muslihati, 2020). Siswa kelas tinggi dapat melakukan pembelajaran dengan mandiri tanpa bantuan orang lain. Seperti membaca buku, mengerjak an tugas, dan lain-lain dengan kehendak atau inisiatif tersendiri tanpa bantuan orang lain. Dalam hal tersebut, siswa mewujudkan kehendak dan keinginannya secara nyata tanpa bergantung pada orang lain (Tasaik \& Tuasikal, 2018). Sehingga dampak dari kemandirian belajar siswa pada pembelajaran jarak jauh ini dapat meningkatkan nilai akademik siswa. 
2167 Faktor-Faktor Penyebab Peningkatan Nilai Siswa Sekolah Dasar dalam Pembelajaran Jarak Jauh pada Masa Pandemi Covid-19 - Nurul Aini Putri, Zulela M.S, Otib Satibi H

DOI: https://doi.org/10.31004/basicedu.v5i4.1171

\section{Peran Orang Tua}

Pembelajaran jarak jauh yang dilaksanakan pada masa pandemi covid-19 saat ini membutuhkan peran yang signifikan dari orang tua untuk dapat menunjang keberlangsungan selama pembelajaran dari rumah. Pelaksanaan pembelajaran jarak jauh yang dimana guru dan murid tidak berada dalam satu tempat dan waktu yang bersamaan, menjadikan orang tua sebagai pengganti guru dalam belajar siswa.

Dari hasil angket yang telah disebar, sebanyak 9 dari 10 siswa kelas 2 menjawab "ya" pada pernyataan dalam mengerjakan tugas sekolah dibantu oleh orang tua. Sedangkan pada siswa kelas 6 sebanyak 10 dari 10 menjawab "tidak" pada pernyataan dalam mengerjakan tugas sekolah dibantu oleh orang tua. Berdasarkan dari hasil tersebut, peran orang tua dalam membantu siswa kelas rendah mengerjakan tugas sangat berpengaruh sehingga nilai siswa mengalami peningkatan. Untuk siswa kelas tinggi sudah dapat mengerjakan secara mandiri tanpa dibantu oleh orang tua.

Berdasarkan hasil tersebut, mengingat pentingnya peran orang tua dalam pelaksanaan pembelajaran jarak jauh bagi peserta didik memberikan dampak pada peningkatan nilai siswa. Orang tua memberikan perhatian, mendampingi serta memberikan semangat pada anaknya dalam kegiatan belajar di rumah (Parlindungan et al., 2020). Pada pembelajaran jarak jauh di masa pandemi covid-19 saat ini peran orang tua yang sangat penting adalah memberikan bantuan pada anaknya bersekolah, mendampingi anak dalam kegiatan di rumah seperti mengerjakan tugas, menciptakan lingkungan yang nyaman bagi anak, dan menjadi contoh bagi anak (Hadi et al., 2021). Peran orang tua dalam membantu atau mendampingi siswa selama belajar dari rumah telah dihimbau melalui Surat Edaran Nomor 15 Tahun 2020 yang diterbitkan oleh Kemendikbud (Sutrah, 2021). Dalam surat tersebut berisi gambaran peran orang tua/wali peserta didik dalam pelaksanaan belajar dari rumah. Orang tua merupakan sosok yang sangat dekat pertemuannya dengan anak sehingga pendampingan dari peran orang tua sangat diperlukan sebagai koordinasi guru dengan orang tua saat anak berlajar dari rumah (Yulianingsih et al., 2020).

\section{Kemudahan Teknologi}

Di era globalisasi saat ini dengan kemajuan perkembangan teknologi yang dapat sangat memudahkan kehidupan manusia. Dalam bidang pendidikan tentunya teknologi memiliki peran dalam kemudahan belajar siswa. Kemudahan dalam belajar merupakan segala sesuatu yang dapat mempermudah dan memperlancar dalam kegiatan pembelajaran (Proborini, 2021). Dalam pelaksanaan pembelajaran jauh saat ini, siswa diberikan kemudahan dalam penggunaan teknologi. Siswa dapat dengan mudah mengakses sumber-sumber materi pelajaran melalui google. Google merupakan sebuah mesin pencarian yang menyediakan berbagai informasi yang ingin dicari.

Dari hasil angket yang telah diisi, sebanyak 8 dari 10 orang siswa kelas 2 menjawab "ya" pada pernyataan mencari jawaban dari tugas yang diberikan guru melalui google. Sedangkan pada kelas 6, sebanyak 9 dari 10 orang siswa menjawab "tidak" pada pernyataan mencari jawaban dari tugas yang diberikan guru melalui google. Hal ini membuktikan bahwa siswa kelas rendah banyak yang menggunakan google untuk mencari jawaban tugas yang diberikan oleh guru.

Dalam pelaksanaan pembelajaran jarak jauh saat ini yang sebagian besar menggunakan pemanfaatan teknologi yang menggunakan internet dalam mencari berbagai hal yang dapat memudahkan siswa dalam belajar (Kurniawati, 2020). Bagi siswa yang merasa kurang dapat memahami pelajaran dari tugas yang diberikan, mereka menggunakan mesin pencarian atau google untuk membantu menyelesaikan pekerjaannya sehingga mendapatkan nilai yang maksimal (Syachtiyani, 2021). Google memberikan kemudahan pada siswa dalam mencari berbagai hal yang ingin dicari oleh siswa tersebut. Dengan hanya memasukkan kata yang akan dicari, dengan mudahnya google memberikan jawaban dari berbagai sumber yang tersedia. Selain dengan dapat meningkatkan nilai siswa dalam belajar, penggunaan google yang memberikan kemudahan siswa dalam belajar juga dapat membentuk perilaku belajar siswa yang menjadi malas membuka buku pegangan fisik yang telah dimiliki (Muthy \& Pujiastuti, 2020). 
2168 Faktor-Faktor Penyebab Peningkatan Nilai Siswa Sekolah Dasar dalam Pembelajaran Jarak Jauh pada Masa Pandemi Covid-19 - Nurul Aini Putri, Zulela M.S, Otib Satibi H

DOI: https://doi.org/10.31004/basicedu.v5i4.1171

\section{Bimbingan Belajar}

Pembelajaran jarak jauh yang telah dilaksanakan tentunya belum sepenuhnya berhasil berjalan dengan baik. Siswa masih belum sepenuhnya memahami materi yang disampaikan guru melalui platform google meet, zoom, google classroom, dan lain sebagianya. Guru telah semaksimal mungkin mengajarkan kepada siswa, namun tentu saja ada keterhambatan penyampaian ilmu dalam pembelajaran jarak jauh ini yang disebabkan oleh jaringan internet. Tidak semua siswa memiliki dan berada pada jaringan internet yang baik dan stabil.

Sehingga untuk dapat lebih memaksimalkan siswa dalam belajar dari rumah, dihadirkannya bimbingan belajar atau private belajar atau pada umumnya disebut dengan les. Bimbingan belajar adalah kegiatan yang membantu peserta didik mengembangkan diri dalam meningkatkan kemampuan dalam pembelajaran (Yektyastuti et al., 2021). Bimbingan belajar merupakan proses interaksi pembimbing dengan yang dibimbing baik secara langsung maupun tidak langsung, yang memiliki tujuan untuk membantu peserta didik dalam mengembangkan potensi diri ataupun memecahkan permasalahan yang dialaminya. Meskipun bimbingan belajar membuat jenuh siswa karena akan mengambil waktu bermain siswa, namun bimbingan belajar jadi pilihan orang tua sebagai sarana untuk membantu peserta didik dalam pembelajaran. Sehingga dapat meningkatkan nilai akademik siswa dan motivasi belajar siswa.

Berdasarkan hasil angket yang disebar, sebanyak 7 dari 10 orang siswa kelas 2 menjawab "ya" pada pernyataan mengikuti bimbingan belajar selama masa pandemi covid-19. Siswa kelas 6 sebanyak 7 dari 10 orang siswa menjawab "tidak" pada pernyataan mengikuti bimbingan belajar selama masa pandemi. Berdasarkan hasil tersebut, siswa kelas rendah lebih banyak yang mengikuti bimbingan belajar dibandingkan siswa kelas tinggi. Orang tua siswa kelas rendah lebih banyak memilih untuk mengikutsertakan anaknya dalam bimbingan belajar selama masa pandemi covid-19.

Layanan bimbingan belajar yang diikuti oleh siswa dapat melalui metode daring dan luring. Bimbingan belajar dengan metode daring, siswa terhubung dengan pembimbing secara virtual melalui platform google meet, zoom, dan yang lainnya. Adapun juga saat ini bimbingan belajar secara daring dapat diakses dengan melalui aplikasi seperti Zenius, Ruang Guru, dan Quipper. Metode bimbingan belajar secara luring yaitu guru dan siswa bertemu secara langsung dalam waktu dan tempat yang sama. Bimbingan belajar secara luring pada masa pandemi covid-19 saat ini dengan menerapkan protokol kesehatan, yaitu memakai masker, mencuci tangan, dan menjaga jarak. Pada pembelajaran jarak jauh yang tentunya ada kekurangan dalam pelaksanaan, bimbingan belajar secara luring atau tatap muka membantu siswa lebih mudah dalam memahami pelajaran dengan maksimal (Mahsuni et al., 2021).

\section{KESIMPULAN}

Dari hasil penelitian yang dilakukan peneliti, dapat disimpulkan bahwa terdapat 4 faktor yang menyebabkan meningkatnya nilai siswa pada masa pembelajaran jarak jauh pandemi covid-19. Faktor yang pertama, kemandirian belajar siswa. Kemandirian belajar siswa pada pembelajaran jarak jauh memberikan dampak meningkatnya nilai akademik siswa. Siswa dengan mandiri dapat melakukan pembelajaran tanpa bantuan orang lain. Faktor kedua, peran orang tua. Dalam pelaksanaan pembelajaran jarak jauh, orang tua menggantikan peran guru saat siswa bersekolah. Peran orang tua yaitu, mendampingi, membantu, dan memberikan fasilitas yang dibutuhkan siswa. Faktor ketiga, kemudahan teknologi. Praktik pembelajaran jarak jauh yang secara daring menggunakan pemanfaatan teknologi. Siswa dapat dengan mudah mengakses segala hal yang ingin dicari melalui google yang dapat memudahkannya dalam belajar. Faktor keempat, bimbingan belajar. Selama pelaksaan pembelajaran jarak jauh, tidak banyak siswa yang masih kurang dapat memahami pembelajaran secara daring. Sehingga siswa mengikuti bimbingan belajar secara daring maupun luring untuk dapat lebih memahami pembelajaran.

Terdapat faktor yang membedakan siswa kelas rendah dengan siswa kelas tinggi pada peningkatan nilai yang terjadi pada pelaksanaan pembelajaran jarak jauh. Faktor peningkatan nilai pada siswa kelas tinggi yaitu 
faktor kemandirian belajar siswa. Sedangkan faktor peningkatan nilai pada siswa kelas rendah yaitu faktor peran orang tua, kemudahan teknologi, dan bimbingan belajar.

Adapun saran dari peneliti yaitu, dari pelaksanaan pembelajaran jarak jauh yang sepenuhnya menggunakan pemanfaatan teknologi, siswa sebaiknya dapat mengerjakan pekerjaan sekolah dengan hasil kemampuan pemahaman siswa. Sehingga siswa tidak bergantung pada jawaban yang diberikan melalui google.

Simpulan menyajikan ringkasan dari uraian mengenai hasil dan pembahasan, mengacu pada tujuan penelitian. Berdasarkan kedua hal tersebut dikembangkan pokok-pokok pikiran baru yang merupakan esensi dari temuan penelitian.

\section{UCAPAN TERIMA KASIH}

Ucapan terima kasih disampaikan kepada pimpinan Fakultas Ilmu Pendidikan Universitas Negeri Jakarta, dosen pengampu atas kesempatannya peneliti memperoleh penelitian ini dan Kepala SDN Rawamangun 01 dan SDT Pelita Hati, beserta staf, para guru, serta peserta didik yang telah membantu pelaksanaan penelitian ini.

\section{DAFTAR PUSTAKA}

Dewi, W. A. F. (2020). Dampak COVID-19 terhadap Implementasi Pembelajaran Daring di Sekolah Dasar. Edukatif: Jurnal Ilmu Pendidikan, 2(1), 55-61. https://doi.org/10.31004/edukatif.v2i1.89

Dong, Y., Dong, Y., Mo, X., Hu, Y., Qi, X., Jiang, F., Jiang, Z., Jiang, Z., Tong, S., Tong, S., \& Tong, S. (2020). Epidemiology of COVID-19 among children in China. Pediatrics, 145(6). https://doi.org/10.1542/peds.2020-0702

Hadi, N. M. F. N. L. K. F. M. P. M. A. N. A. D. I. N. Y. H. (2021). Penguatan Peran Orang Tua Dalam Membangun Pendidikan Pada Pembelajaran Jarak Jauh (PJJ) di Era Pandemi Covid-19. Indonesian Journal of Community Services in Engineering \& Education (IJOCSEE), 1(1), 46-55. http://ejournal.upi.edu/index.php/IJOCSEE/

Kurniawati, D. (2020). Pengaruh Penggunaan Gadget terhadap Prestasi Siswa. Edukatif: Jurnal Ilmu Pendidikan, 2(1), 78-84. https://doi.org/10.31004/edukatif.v2i1.78

Mahsuni, A. W., Nadhif, A., Rahayu, E., Maghfiroh, M., Lestari, I. D., Valentino, L. F., Aprilianti, E. D., \& Faruq, A. (2021). Pembelajaran Home Visited Dalam Masa Pandemi covid-19. Jurnal Pembelajaran Pemberdayaan Masyarakat, 2(1), 1-6.

Muthy, A. N., \& Pujiastuti, H. (2020). Analisis media pembelajaran e-learning melalui pemanfaatan teknologi dalam pembelajaran matematika di rumah sebagai dampak 2019-nCoV. Jurnal Math Educator Nusantara: Wahana Publikasi Karya Tulis Ilmiah Di Bidang Pendidikan Matematika, 6(1), 94-103. https://doi.org/10.29407/jmen.v6i1.14356

Parlindungan, D. P., Ghani, M. Al, \& Nurhaliza, S. (2020). Peranan guru dan orang tua dalam menghadapi pembelajaran jarak jauh (pjj) dimasa pandemi covid-19 di sds islam an-nuriyah. Prosiding Nasional Penelitian LPPM UMJ, 1-10. https://jurnal.umj.ac.id/index.php/semnaslit/article/view/8795

Proborini, E. (2021). Evaluasi Pembelajaran Matematika Secara Daring Pada Siswa Kelas Vi Sd Karangturi. Intelligentes Jurnal Pendidikan Fisika Dan Sains, 2.

Putri, R. N. (2020). Indonesia dalam Menghadapi Pandemi Covid-19. Jurnal Ilmiah Universitas Batanghari Jambi, 20(2), 705. https://doi.org/10.33087/jiubj.v20i2.1010

Rozi, F., Lana, I. F., \& Jadid, U. N. (2021). Meningkatan Kemandirian Belajar Siswa. Jurnal Pendidikan Dasar, 5(1), 109-124. https://ejournal.stitpn.ac.id/index.php/fondatia

Setiawan, A. R. (2020). Lembar Kegiatan Literasi Saintifik untuk Pembelajaran Jarak Jauh Topik Penyakit Coronavirus 2019 (COVID-19). Edukatif: Jurnal Ilmu Pendidikan, 2(1), 28-37.

https://doi.org/10.31004/edukatif.v2i1.80 
2170 Faktor-Faktor Penyebab Peningkatan Nilai Siswa Sekolah Dasar dalam Pembelajaran Jarak Jauh pada Masa Pandemi Covid-19 - Nurul Aini Putri, Zulela M.S, Otib Satibi H

DOI: https://doi.org/10.31004/basicedu.v5i4.1171

Sulastrini \& Muslihati. (2020). Rancangan Implementasi Kemandirian Belajar dalam Konteks Pandemi Covid19 berdasarkan Perspektif Freedom to Learn Rogers. Prosiding Seminar Bimbingan Dan Konseling, 92 98.

Sutisna, A. (2021). Metode Penelitian Kualitatif Bidang Pendidikan. Jakarta: UNJ PRESS.

Sutrah, A. (2021). Peran Orang Tua dalam Pembelajaran Anak di Masa Pandemi. PEMBELAJAR: Jurnal Ilmu Pendidikan, Keguruan, Dan Pembelajaran, 5(1), 5-14. http://dx.doi.org/10.31219/osf.io/nsv42

Suwendra, W. I. I. B. A. L. M. (2018). Metodologi Penelitian Kualitatif dalam Ilmu Sosial, Pendidikan, Kebudayaan dan Keagamaan. Badung: Nilacakra.

Syachtiyani, W. R. N. T. (2021). Analisis Motivasi Belajar Dan Hasil Belajar Siswa Di Masa Pandemi Covid19. Prima Magistra: Jurnal Ilmiah Kependidikan, 2(1), 90-101. https://doi.org/10.37478/jpm.v2i1.878

Tasaik, H. L., \& Tuasikal, P. (2018). Peran Guru Dalam Meningkatkan Kemandirian Belajar Peserta Didik Kelas V Sd Inpres Samberpasi. Metodik Didaktik, 14(1), 45-55. https://doi.org/10.17509/md.v14i1.11384

Yektyastuti, R., Nuroniah, L., -, F., \& Andiani, M. (2021). Rumah Pintar : Bimbingan Belajar Siswa Sekolah Dasar di Masa Pandemi Covid-19. Educivilia: Jurnal Pengabdian Pada Masyarakat, 2(1), 83. https://doi.org/10.30997/ejpm.v2i1.3585

Yulianingsih, W., Suhanadji, S., Nugroho, R., \& Mustakim, M. (2020). Keterlibatan Orangtua dalam Pendampingan Belajar Anak selama Masa Pandemi Covid-19. Jurnal Obsesi : Jurnal Pendidikan Anak Usia Dini, 5(2), 1138-1150. https://doi.org/10.31004/obsesi.v5i2.740

Yunitasari, R., \& Hanifah, U. (2020). Pengaruh Pembelajaran Daring terhadap Minat Belajar Siswa pada Masa COVID 19. Edukatif: Jurnal Ilmu Pendidikan, 2(3), 232-243. https://doi.org/10.31004/edukatif.v2i3.142 